\title{
The effect of the implementation of evidence-based drug formulary on antibacterial use in a private hospital at Tanjung Enim, Sumatera Selatan, Indonesia
}

\author{
Erna Kristin ${ }^{1 *}$, Dwi Indria Anggraini ${ }^{2}$, Jarir At Thobari ${ }^{1}$, Alfi Yasmina ${ }^{3}$ \\ 1'Department of Pharmacology and Therapy, Faculty of Medicine, Universitas Gadjah Mada, \\ Yogyakarta, ${ }^{2}$ Department of Pharmacology, Faculty of Medicine, Lampung University, \\ Tanjung Karang, ${ }^{3}$ Department of Pharmacology, Faculty of Medicine, Lambung Mangkurat \\ University, Banjarmasin, Indonesia
}

DOI: http://dx.doi.org/10.19106/JMedSci004901201703

\section{ABSTRACT}

The increase of drug expenditure in the hospital has facilitated the implementation of an evidence-based drug formulary. The aim of this study was to assess the change in antibacterial use after the implementation of an evidence-based drug formulary in a private hospital at Tanjung Enim, Sumatera Selatan, Indonesia. This study used a preposttest design. Drug use data in the period before (2010-2011) and after (2012-2013) the formulary implementation were extracted from the hospital medical records. The drug use in the hospital before and after the implementation was compared using t-test and chi-square test, with the significance level of 0.05 . Average number of drugs prescribed per prescription after the implementation was similar with that before the implementation (4.4 vs $4.6 ; p>0.05)$. However, the proportion of generic drugs prescribed increased significantly after the formulary implementation $(17.0 \%$ vs $52.7 \% ; p<0.05)$. Moreover, it was still significantly increased when the analysis was conducted only for antibacterial drugs $(25.9 \%$ vs $72.0 \% ; p<0.05)$. Average drug cost per prescription was $34 \%$ lower after the intervention $(p<0.05)$, and the average cost for antibacterial drug was also decreased $(26 \%)$. The use of antibacterial drugs was significantly decreased after the intervention $(12.5 \%$ vs $6.9 \% ; p<0.05)$. The most often antibacterial drugs prescribed before the interventions were beta-lactams and macrolides; while quinolones were more increasingly used after the intervention. In conclusion, the implementation of evidencebased hospital drug formulary in a private hospital at Tanjung Enim, Sumatera Selatan significantly increase generic drug use and decreased antibacterial use and average drug cost per prescription.

\section{ABSTRAK}

Peningkatan belanja obat di rumah sakit menyebabkan dibuatnya formularium obat berbasis bukti. Tujuan dari penelitian ini adalah untuk menilai perubahan penggunaan antibakteri setelah implementasi formularium obat berbasis bukti di rumah sakit swasta di Tanjung Enim, Sumatera Selatan, Indonesia. Penelitian ini menggunakan rancangan prepost tes menggunakan data rekam medik rumah sakit dari periode sebelum (2010-2011)

Corresponding author: erna_kristin@ugm.ac.id 
dan setelah (2012-2013) implementasi formularium. Indikator penggunaan obat sebelum dan sesudah implementasi dibandingkan dengan menggunakan uji t dan chi square, dengan tingkat signifikansi 0,05 . Jumlah rata-rata obat yang diresepkan perlembar resep sebelum dan setelah implementasi setara $(4,4$ vs 4,$6 ; p>0,05)$. Namun, proporsi obat generik yang diresepkan meningkat secara nyata setelah penerapan formularium $(17,0$ vs $52,7 \% ; p<0,05)$. Selain itu peningkat secara nyata masih dijumpai ketika analisis dilakukan hanya untuk antibakteri $(25,9$ vs $72,0 \% ; p<0,05)$. Rata-rata biaya obat per resep adalah $34 \%$ lebih rendah setelah implementasi $(p<0,05)$ dan biaya rata-rata untuk antibakteri juga menurun $(26 \%)$. Penggunaan antibakteri secara nyata menurun setelah implementasi $(12,5$ vs $6,9 \% ; p<0,05)$. Antibakteri yang paling sering diresepkan sebelum implementasi adalah beta-laktam dan makrolida, sementara kuinolon yang lebih semakin digunakan setelah implementasi. Kesimpulan, implementasi formularium obat rumah sakit berbasis bukti di rumah sakit swasta Tanjung Enim, Sumatra Selatan meningkatkan secara nyata penggunaan obat generik dan menurunkan penggunaan antibakteri serta biaya obat rata-rata per resep.

Key words : drug formulary - prescribing pattern - generic drug - antibacterial - private hospital

\section{INTRODUCTION}

In developing countries like Indonesia, disease patterns have changed from infectious diseases to cardiovascular diseases. However, infectious diseases are still crucial problems in public health. To treat various infectious diseases, the total cost to be spent for antibacterial drugs is not inexpensive. ${ }^{1,2}$

In its journey, the use of antibacterial drugs tend to be excessive and these drugs are generally given to diseases or conditions that do not need antibacterial drugs. ${ }^{3,4}$ Other studies also found similar conditions, namely, patients who received inadequate antibacterial drugs, or those who were given these drugs before the results from culture from respiratory tract secretions, blood, or pleural fluid were obtained, had higher mortality rate compared to those who had their pathogenic bacteria identified before treatment. ${ }^{5}$

The forms of irrational antibacterial use are quite diverse, from an inappropriate choice of antibacterial to various methods of administration and duration of use. The habit of prescribing antibacterial in inappropriate dose (usually under-dose), incorrect frequency, or for a too short or too long duration will reduce their efficacy and create serious resistance problem. ${ }^{6}$

In order to ensure appropriate and rational use of antibacterial, particularly in the healthcare institution/hospital environment, the principles of antibacterial stewardship should be applied consistently. One of the principles is the development of evidencebased formulary. The development of this formulary along with continuous education on antibacterial use are essential approaches to be applied, and medical practitioners should follow the us education periodically. ${ }^{7,8}$ The study was performed to assess the change in antibacterial use after the implementation of an evidence-based drug formulary in a private hospital at Tanjung Enim, Sumatera Selatan, Indonesia.

\section{MATERIALS AND METHODS}

This study used a pre-posttest design. The intervention was the implementation of a new drug formulary, emphasizing on evidence- 
based treatment and generic formulation. The development of evidence-based formulary was conducted after data collection and analysis in 2010-2011 at a private hospital at Tanjung Enim, Sumatera Selatan, Indonesia. Based on data in 2010-2011, the draft of evidence-based formulary was prepared. Expert review was conducted on the formulary draft before the implementation in healthcare. This study analyzed more data 2 years after the implementation, namely 2012-2013. Drug use data in the period before (20102011) and after the formulary implementation (2012-2013) were extracted from the hospital medical records. The drug use in hospital before and after the intervention $\mathrm{w}$ compared using t-test and chi-square test, with the significance level of 0.05. Drug use items compared were the average numbers of drugs prescribed per prescription, the proportions of generic drugs prescribed, average drug costs per prescription, and the proportions of drug therapeutic classes. Generic drug proportions and average drug costs were also compared specifically for antibacterial drugs.

\section{RESULTS}

There were 35,032 prescriptions before the formulary implementation and 8,255 prescriptions after the formulary implementation. TALE 1 summarizes the comparison of the prescriptions before and after the evidence-based formulary implementation. There was no difference in the average number of drugs prescribed per prescription before and after the formulary implementation (4.4 vs 4.6; $\mathrm{p}>0.05$ ). The proportion of generic drugs prescribed was significantly higher after the formulary implementation (17.0 vs 52.7\%; p < 0.01). The average drug cost per prescription was significantly lower after the implementation of formulary (before vs after 261.900 vs IDR 172.600; $\mathrm{p}<0.01)$.

TABLE 1. Characteristics of prescriptions before and after the formulary implementation

\begin{tabular}{lccc}
\hline \multicolumn{1}{c}{ Characteristics } & $\begin{array}{c}\text { Before } \\
\text { Implementation }\end{array}$ & $\begin{array}{c}\text { After } \\
\text { Implementation }\end{array}$ & $\mathrm{p}$ \\
\hline $\begin{array}{l}\text { Number of drug per } \\
\text { prescription (mean } \pm \text { SD) }\end{array}$ & $4.4 \pm 1.7$ & $4.6 \pm 2.2$ & $>0.05$ \\
$\begin{array}{l}\text { Proportion of generic drugs } \\
\text { prescribed (\%) }\end{array}$ & 17.0 & 52.7 & $<0.01$ \\
$\begin{array}{l}\text { Drug cost per prescription } \\
\text { (IDR) }\end{array}$ & & & \\
Mean \pm SD & $261.900 \pm 258.6$ & $172.600 \pm 512.8$ & $<0.01$ \\
Median & 189.600 & 80.800 & \\
\hline
\end{tabular}

Note: $\mathrm{IDR}=$ Indonesian rupiah, $\mathrm{SD}=$ standard deviation

TABLE 2 shows the change of prescription of systemic antibacterial drug classes before and after the formulary implementation. There were significant decreases in the proportions of tetracyclines ( 0.5 vs $0.2 \%)$, penicillins (19.5 vs $9.0 \%$ ), other beta-lactams (43.0 vs $30.0 \%)$, macrolides and lincosamides (19.9 vs $17.5 \%)$ prescribing after the implementation 
of evidence-based formulary compared to before the implementation. Meanwhile, the proportions of amphenicols (0.9 vs $2.6 \%)$, sulfonamides and trimethoprim (3.4 vs $6.1 \%)$, aminoglycosides (0.0 vs $1.0 \%)$, quinolones
(12.8 vs $32.1 \%)$, and other antibacterial drugs ( 0.0 vs $1.4 \%)$ after formulary implementation were significantly higher compared to those before the implementation.

TABLE 2. Changes in the prescribing of systemic antibacterial drug classes before and after the evidence-based formulary implementation

\begin{tabular}{lccc}
\hline Antibacterial drug class & $\begin{array}{c}\text { Before } \\
\text { Implementation (\%) }\end{array}$ & $\begin{array}{c}\text { After } \\
\text { Implementation } \\
(\%)\end{array}$ & $\mathrm{p}$ \\
\hline Tetracyclines & 0.5 & 0.2 & $<0.01$ \\
Amphenicols & 0.9 & 2.6 & $<0.01$ \\
Beta-lactam antibacterials: penicillins & 19.5 & 9.0 & $<0.01$ \\
Other beta-lactam antibacterial drugs & 43.0 & 30.0 & $<0.01$ \\
Sulfonamides and trimethoprim & 3.4 & 6.1 & $<0.01$ \\
Macrolides, lincosamides & 19.9 & 17.5 & $<0.01$ \\
Aminoglycosides & 0.0 & 1.0 & $<0.01$ \\
Quinolones & 12.8 & 32.1 & $<0.01$ \\
Other antibacterial drugs & 0.0 & 1.4 & $<0.01$ \\
\hline
\end{tabular}

In TABLE 3, it is shown that the prescription of generic antibacterial drugs increased significantly after the formulary implementation $(24.4 \%$ vs $72.0 \%, \mathrm{p}<0.01)$.
With the implementation of the formulary, the average cost for antibacterial drugs decreased significantly from IDR 241.700 per prescription to IDR $180.100(\mathrm{p}<0.01)$.

TABLE 3. Characteristics of antibacterial drug prescriptions before and after the formulary implementation

\begin{tabular}{lccc}
\hline Characteristics & $\begin{array}{c}\text { Before } \\
\text { Implementation }\end{array}$ & $\begin{array}{c}\text { After } \\
\text { Implementation }\end{array}$ & $\mathrm{p}$ \\
\hline $\begin{array}{l}\text { Proportion of generic antibacterial } \\
\text { drugs prescribed (\%) }\end{array}$ & $24.4 \%$ & $72.0 \%$ & $<0.01$ \\
$\begin{array}{l}\text { Antibacterial drug cost per } \\
\text { prescription (IDR) }\end{array}$ & & & \\
Mean \pm SD & $241.700 \pm 179.7$ & $180.100 \pm 401.6$ & $<0.01$ \\
\hline Median & 197.500 & 55.600 & \\
\hline
\end{tabular}

Note: $\mathrm{IDR}=$ Indonesian rupiah, $\mathrm{SD}=$ standard deviation 


\section{DISCUSSION}

In order to use antibacterial drugs appropriately and rationally, particularly in the healthcare institution/hospital environment, the principle of antibacterial stewardship should be applied consistently. Continuous education on the use of antibacterial drugs is an essential approach that is needed to be applied and medical practitioners should follow it periodically. The evidence-based treatment approach for infectious diseases based on the results of current studies is really needed to update the knowledge in antibacterial drug use. $^{9-12}$

Patterson et al. reported that $92 \%$ antibacterial drug prescribing by general practitioners for otitis media was inappropriate, and based on microbiological analysis, there were no bacteria found. The type of antibacterial prescribed was often incorrect because the prescribing was generally not consistent with the suspected pathogenic bacteria. $^{13,14}$

There are some efforts that can be done to control irrational drug use, including managerial, operational, and educational approaches. The managerial effort includes the application of strategy and policy which is basically aimed to increase the quality of prescribing, namely, rational prescribing. Strategy to carry out this effort includes increasing the quality of prescribing through various educational approach. Health service should equip itself with updated information and provide guidance to optimize drug use. To achieve this, principles of evidence-based medicine should be applied correctly. ${ }^{15,16}$

Inadequate and inappropriate antibacterial drug use is often found in daily practice, both in primary health service and in hospitals. Various studies found that inappropriate prescribing of antibacterial lead to the risk of unknown adverse effects and bacterial resistance in the long run, and these will increase the morbidity and mortality. Based on the current scientific evidence, there are a lot of unnecessary antibacterial drug use.

Evidence-based medicine formulary is developed to provide a guidance for doctors and medical practitioners to provide treatment optimally based on current scientific evidence that is reliable and scientifically accountable. Efforts in keeping up-to-date with current treatment information should become an integral part of public health service.

One of the important steps in the treatment process is drug selection. In this step, a medical practitioner should determine the type of drugs needed by the patients. Prescribed drugs should be the most efficacious and safe for the patients. Unfortunately, often the decisionmaking the process to choose drugs is not based on the most recent and valid scientific evidence.

One of the interesting phenomena often escapes our attention is the variability between clinicians in choosing the type of drugs for the patients. This variability in choosing antibacterial for one indication leads to high drug cost and increased risk of bacterial resistance in the particular healthcare unit ${ }^{17,18}$

In health service such as a hospital, this problem can be solved by providing a formulary. With this formulary, drugs used are those that are really needed, avoiding the excessive cost to buy unnecessary drugs. Drug selection also means to select only drug-ofchoice, while avoiding to provide unnecessary drugs, particularly if they are not supported by convincing scientific evidence. With a good formulary, a hospital indirectly ensures the availability of drugs with the best efficacy and safety, while drugs with questionable benefit are not provided. This system will increase 
patient trust to a medical practitioner because they understand that the prescribed drugs are drugs of choice that have been thoroughly studied in terms of efficacy, quality, and safety. ${ }^{19,20}$

Research conducted a study comparing drug cost before and after drug formulary implementation. In this study, it was found that the application of drug formulary reduced drug cost more than $50 \%$ in a relatively short period. ${ }^{21}$

\section{CONCLUSION}

The implementation of evidence-based hospital drug formulary in a private hospital at Tanjung Enim, Sumatera Selatan significantly increases generic drug use and decreases antibacterial use and average drug cost per prescription.

\section{ACKNOWLEDGMENTS}

We would like to show our gratitude to the Director of the private hospital at Tanjung Enim Sumatra Selatan for sharing their data.

\section{REFERENCES}

1. Oni $\mathrm{T}$, McGrath N, BeLue R, Roderick P, Colagiuri S, May $\mathrm{CR}$, et al. Chronic diseases and multi-morbidity--a conceptual modification to the WHO ICCC model for countries in health transition. BMC Public Health 2014;14:575. DOI: 10.1186/14712458-14-575.

https://doi.org/10.1186/1471-2458-14-575

2. Remais JV, Zeng G, Li G, Tian L, Engelgau $\mathrm{MM}$. Convergence of non-communicable and infectious diseases in low- and middle-income countries. Int J Epidemiol 2013; 42(1):221-7. https://doi.org/10.1093/ije/dys135

3. Simonse GS, Tapsall JW, Allegranzi B, Talbot EA \& Lazzari S. The antimicrobial resistance containment and surveillance approach - a public health tool. Bull World Health Organ 2004; 82(12):928-34.

4. Metlay JP, Shea JA, Crossette LB, Asch DA. Tension in antibiotic prescribing. Pitting social concerns against the interests of individual patients. J Gen Intern Med 2002; 17:87-94.

https://doi.org/10.1046/j.15251497.2002.10711.x

5. Briassoulis G, Natsi L, Tsorva A, Hatzis T. Prior antimicrobial therapy in the hospital and other predisposing factors influencing the usage of antibiotics in a pediatric critical care unit. Ann Clin Microb Antimicrob 2004, 3:4. DOI: $10.1186 / 1476-0711-3-4$ https://doi.org/10.1186/1476-0711-3-4

6. Høgli JU, Garcia BH, Skjold F, Skogen V and Småbrekke L. An audit and feedback intervention study increased adherence to antibiotic prescribing guidelines at a Norwegian hospital. BMC Infect Dis 2016; 16:96. DOI: $10.1186 / \mathrm{s} 12879-016-1426-1$. https://doi.org/10.1186/s12879-016-1426-1

7. Pulcini $\mathrm{C}$ and Gyssens IC. How to educate prescribers in antimicrobial stewardship practices Virulence 2013; 4(2): 192-202. https://doi.org/10.4161/viru.23706

8. Doron D, Davidson LE. Antimicrobial Stewardship. Mayo Clin Proc 2011; 86(11):1113-23. https://doi.org/10.4065/mcp.2011.0358

9. Özgenç O. Methodology in improving antibiotic implementation policies World $\mathrm{J}$ Methodol 2016; 6(2):143-53. DOI: 10.5662/ wjm.v6.i2.143. https://doi.org/10.5662/wjm.v6.i2.143

10. Moe-Byrne T, Chambers D, Harden M, McDaid C. Behaviour change interventions to promote prescribing of generic drugs: a rapid evidence synthesis and systematic review. BMJ Open 2014; 4(5):e004623. DOI: 10.1136/bmjopen-2013-004623.

https://doi.org/10.1136/bmjopen-2013004623 
11. Toverud E-L, Hartmann K, Hakonsen H. A systematic review of physicians' and pharmacists' perspectives on generic drug use: what are the global challenges? Appl Health Econ Health Policy 2015; 13 (Suppl 1): S35-S45. DOI: 10.1007/s40258-0140145-2 https://doi.org/10.1007/s40258-014-0145-2

12. Masiero G, Filippini M, Ferech M, Goossens H. Socioeconomic determinants of outpatient antibiotic use in Europe. Int J Public Health 2010; 55:469-78. https://doi.org/10.1007/s00038-010-0167-y

13. Patterson CA, Mackson JM, Weekes LM. Antibiotic prescribing for upper-respiratorytract infections in primary care. Commun Dis Intell 2003; 27 Suppl: S39-S41

14. Schechner V, Temkin E, Harbarth S, Carmeli Y,a, Schwaberb MJ. Epidemiological interpretation of studies examining the effect of antibiotic usage on resistance. Clin Microbiol Rev 2013; 26(2): 289-307. https://doi.org/10.1128/CMR.00001-13

15. World Health Organization. Promoting rational use of medicines: core components. Geneva: World Health Organization, 2002.

16. Reed EE, Stevenson KB, West JE, Bauer KA, Goff DA. Impact of formulary restriction with prior authorization by an antimicrobial stewardship program. Virulence 2013; 4(2): 158-62.

https://doi.org/10.4161/viru.21657
17. Alsan M, Schoemaker L, Eggleston K, Kammili N, Kolli P, Bhattacharya J. Out-ofpocket health expenditures and antimicrobial resistance in low- and middle-income countries. Lancet Infect Dis 2015; 15(10): 1203-210. https://doi.org/10.1016/S1473-3099(15) 00149-8

18. Chandy SJ, Naik GS, Charles R, Jeyaseelan V, Naumova EN, Thomas K, et al. The impact of policy guidelines on hospital antibiotic use over a decade: a segmented time series analysis. PLoS ONE 2014; 9(3): e92206. https://doi.org/10.1371/journal.pone.0092206

19. Bassetti M, Di-Biagio A, Rebesco B, Amalfitano ME, Topal J, Bassetti D. The effect of formulary restriction in the use of antibiotics in an Italian hospital. Eur J Clin Pharmacol 2001;57:529-34. https://doi.org/10.1007/s002280100338

20. Infectious Diseases Society of America (IDSA). Combating antimicrobial resistance: policy recommendations to save lives. Clin Infect Dis. 2011; 52 (suppl 5): S397-S428 https://doi.org/10.1093/cid/cir153

21. Chiefari DM. Effect of a highly restrictive formulary on the average prescription cost at a community health center. Am J Health-Syst Pharm 2000; 57:846-7. 